\title{
Obituaries
}

Obituaries should be submitted by email to Laura Pacey at I.pacey@nature.com.

All submitted obituaries should be 350 words maximum in length (apart from obituaries for past presidents of the BDA where the length should be $700-800$ words).

Content of the obituary is down to the individual author, and the approval of the family should be given for the obituary prior to submission to the $B D J$.

\section{ALAN CAPLETON}

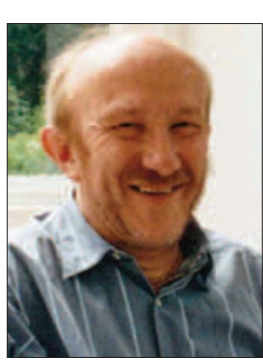

Alan was born and raised in Liverpool in 1938 and attended Merchant Taylors' School. When he left school he completed his National Service and in 1963 married Betty and moved to Norwich where he worked as a representative for a medical firm. He always had the ambition to become a dentist, so in 1968 he returned with his family to Liverpool and started his studies at Liverpool University Dental School.

Alan was a mature student and those of us fortunate enough to be in his year looked up to him and benefitted from his experience of life. He loved the challenge of helping people solve their problems. He had a very easy manner and a well developed, mischievous sense of humour, which he used often to the delight of those around him.

After qualification the family returned to Norwich and joined a practice in Unthank Road. Although he suffered a stroke in 1975, he was able to continue to practice very successfully. He attracted the most challenging patients because of his lovely manner; those that were terrified and needed lots of time found him gentle and kind. His appointments nearly always ran late but patients didn't mind because when they sat in the chair they forgot their fear as he joked with them and told stories about his family of whom he was very proud. He retired in 2002 after 28 years in practice. He and Betty were regular attendees of the reunions held by our year group.
Away from dentistry, Alan was a member and past president of the Hethersett and District Lions Club. He had a passion for cars and at one point was the proud owner of two Jensens. He was fascinated by the latest technology and a leader in using it.

Alan died on 10 October 2011 and leaves his wife, Betty, four children and seven grandchildren to whom he was devoted.

\section{John F. Hawkins}

\section{BRYN MORRIS JONES}

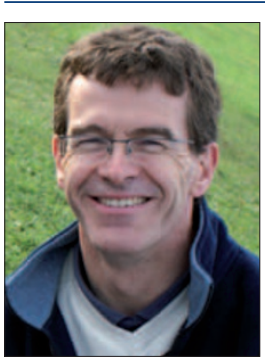

Bryn was a wellknown and highly respected dentist working with the Community Dental Service in North West Wales. He was very well liked both professionally

and personally by everyone who had the privilege of knowing him.

He was born in Tywyn, Merionydd in 1957, moving with his family to Bangor, North Wales where he completed his secondary education at Ysgol Dyffryn Ogwen. He studied dentistry at Cardiff University (or the Welsh National School of Medicine and Dentistry at it as it was then known) graduating in 1982.

His early years post-graduation were spent in general dental practice in Bangor from where he joined the Community Dental Service. His particular interests were anaesthetics and epidemiology but he played a full role in the service provision for the area.

For the last 20 years Bryn was a founding and leading member of $Y$ Gymdeithas Ddeintyddol (a Dental
Society which is a scientific and social organisation giving Welsh dentists the opportunity to discuss dental and allied matters through the medium of the Welsh language). Given that the majority of scientific and dental education is carried out through the medium of English, it soon became apparent that a dictionary of dental terms translated into Welsh was urgently needed. Bryn took a leading role in this project, displaying his usual meticulous care and conscientiousness in the work. This led to the publication of $Y$ geiriadur deintyddol (the dental dictionary) of about 5,000 words, which won a Welsh healthcare publications award.

Bryn was the chairman of this society at the time of his shockingly untimely death. Under his inspiring guidance, the society was about to launch a website and, in conjunction with the BDA, produce patient information leaflets in Welsh. Both projects have been driven forward largely due to his efforts.

Bryn had been happily married for 27 years to Jan, and was a proud and devoted father to Llyr, Gwion, Branwen and Non.

His family, friends and professional colleagues and patients will greatly miss Bryn's good humour and forbearance but will be glad to have known him, despite his passing at the height of his powers.

Rhys Davies

In honour of Bryn's contribution to dentistry in the Welsh language, a Welsh translation of his obituary can be found online and accessed from the BDJ website (www.bdj.co.uk), under 'Obituaries' in the table of contents for Volume 212 issue 10. 